\title{
Assessment the Influence and Efficacy of Some Biocides on Rice Plants
}

\author{
B.B. Rath $^{1}$ and S. P. Adhikary ${ }^{2 *}$ \\ ${ }^{1}$ Department of Botany, RHSS, Ramgiri, Dist. - Gajpati, Odisha, India \\ ${ }^{2}$ Department of Botany, Aska Science College, Aska, Dist. - Ganjam, Odisha, India \\ *Corresponding author
}

\begin{abstract}
A B S T R A C T
In tropical countries rice has been identified as one of the crops that are particularly susceptible to the negative impacts of pesticide use. In addition to the physicochemical

Keywords

Rice, Neem oil,

Carbosulfan and oxadiargyl nature of the pesticide, tropical climatic conditions and agricultural practices play important roles in determining the fate and distribution of pesticides in the tropical paddy field ecosystem. The assessment of toxicological effects of pesticides in the tropical paddy has been evaluated through seed germination percentage, vegetative parameters and chlorophyll content. The seedlings are the crucial stage of the plant, so, the experimental study evaluated 14 days old seedling's vegetative growth parameters and chlorophyll content and percentage of seed germination influenced by different biocides (neem oil, carbosulfan and Oxadiargyl). The experimental results found that all concentrations of

Accepted: 10 September 2018 Available Online: 10 October 2018 $(0.5,1.5,2.0,2.5,3.0,3.5,4.0,4.5,5.0 \mathrm{ml} / \mathrm{l})$ neem oil, carbosulfan and oxadiargyl decreased the percentage of seed germination, vegetative parameters and chlorophyll content. Out of these three biocides, neem oil was found less toxic towards the test cultivar. Effective training of the paddy farmer has been identified as the key to successful implementation of integrated pest management strategies for more productivity.
\end{abstract}

\section{Introduction}

Rice is an important crop in southern part of Odisha. About $70 \%$ people depend on cultivation of rice for their livelihood. To maximize rice yields, sustainable management of the crop is needed to control the main pests that limit rice growth and development. It is necessary to use biocides and pesticides. Neem oil act as biocides due to its active ingredient azadirachtin substances with pesticidal properties are found in all parts of the neem tree. Azadirachtin consists of more than 25 different but closely related compounds act as pesticides which are currently available. Azadirachtin can act as a feeding deterrent against a number of insect pests including beetles. It reduces the level of the insect hormone Ecdysome by disrupting the insect's molting process so that the immature larvae cannot develop into adults.

After treatment with neem-based pesticides insects are either die or crippled with distorted wings or the immature larvae and nymphs remain in an immature stage and then die. Adults are not killed by the growth regulating properties of azadirachtin but mating and 
sexual communication may be disrupted which results in reduced fecundity (Schmutter, 1990). Neem oil works in a number of different ways. The oil forms a coating on the insect's body, blocking the breathing openings and suffocating the insect. It also has a repellent effect on certain insects and mites. Neem oil prevents the germination and penetration of some fungal spores. One percent neem oil treatment was effective in managing powdery mildew on hydrangeas, lilacs and phlox.

Carbosulfan shows a good agronomic efficiency, this insecticide has environment restrictions due to the risks of contamination. One problem frequently associated to the carbofuran is the death of forest animais if they contaminated with it. Dietrich et al., (1995) found similar problems for the carbofuran granules applied in field crops in Swiss. According to Crepeau and Kuivila (2000), the continuous presence of carbofuran in water channels and rivers might cause severe, sub-lethal or chronic damages to aquatic organisms. Gupta (1994) observed that carbofuran is toxic to micro crustaceous and vertebrates of a same food chain. NorbergKing et al., (1991) affirm that carbofuran is a toxic insecticide to the aquatic wildlife. The use of carbofuran in agriculture is prohibited in some countries (Anonymous, 1996a; Anonymous, 1996b; James, 1995) due to its eco-toxicity. The carbofuran persistence in the paddy water and in soil solution has been studied in tablelands and channels, because carbofuran is degraded mainly by hydrolysis (Seiber et al., 1978; Tejada and Magallona, 1985 and Trevizan et al., 2002). The degradation process of carbofuran (2, 3dihydro-2, 2-dimethyl-7-benzofuranol methylcarbamate) molecule (represented as $\mathrm{RX}$ ) occurs when it reacts with the water molecule originating a new $\mathrm{C}-\mathrm{N}$ bond and breaking a $\mathrm{C}-\mathrm{X}$ bond in the original molecule. The net reaction is essentially a direct displacement of X by OH (Seiber et al., 1978 and Mabury and Crosby, 1996). The volatilization, photolysis and oxidation are important factors in the process of carbofuran dissipation (Seiber et al., 1978; Deuel et al., 1979). Carbosulfan (2, 3-dihydro-2, 2dimethyl-7-benzofuranyl (di-nbutylaminosulfenyl) (methylcarbamate) as substituted carbofuran as insecticide, because of environmental reasons and of its lower persistence. According to Marsden et al., (1982) and Umetsu and Fukuto (1982), carbosulfan presents lower toxicity for the aquatic wildlife than carbofuran. Tejada and Magallona (1985) demonstrated that carbosulfan was not detected in samples of paddy water and soil solution collected few hours after its application. Hydrolysis is the main path of carbosulfan to carbofuran degradation, its first metabolite, but in some cases, th is latter might present longer persistence in a low $\mathrm{pH}$ environment (Ramanand et al., 1991). Other environmental factors, such as temperature variation, might directly influence the carbosulfan degradation process (Sahoo et al., 1990).

Oxadiargyl acts as protoporphyrinogen IX oxidase inhibitor. It is pre-emergence and early post-emergence herbicide active on broad-leaved weeds (Amaranthus, Bidens, Chenopodium, Malva, Monochoria, Polygonum, Portulaca, Potamogeton, Raphanus, Solanum, Sonchus, Rotala), grasses (Echinochloa, Leptochloa, Brachiaria, Cenchrus, Digitaria, Eleusine, Panicum and wild rice) and annual sedges, in rice, upland crops (sunflower, potato, vegetables and sugar cane) and perennial crops (fruit trees and citrus). Plants Studies on lemons, sunflowers and rice demonstrated very low levels of residues at harvest, mainly parent compound (Leake et al., 1998). Soil/Environment DT50 (lab., aerobic) 18-72 d (20-30 $\left.{ }^{\circ} \mathrm{C}\right)$, forming two major metabolites (one of which is herbicidal) which are, in turn, steadily 
degraded, resulting in mineralisation to $\mathrm{CO}_{2}$ and a soil-bound residue. Oxadiargyl dissipates rapidly from water into the sediment phase and is readily degraded under anaerobic conditions. Strongly adsorbed to soil (Koc 1000-3000); oxadiargyl and its two major soil metabolites show low mobility in 4 soil types and are unlikely to leach. Field results were consistent: DT50 9-25 d, mean DT90 90 d; for oxadiargyl and its two major metabolites, DT50 was 9-31 d, DT90 65-234 d; >95\% of oxadiargyl residues remained in the top $10 \mathrm{~cm}$ of soil, and no residues were found below 30 $\mathrm{cm}$. Oxadiargyl is a potential herbicide in crops such as lettuce and capsicums (Dickmann et al., 1997).

Investigation of these pesticides is of the utmost importance for a better understanding of their dynamics in the environment. The literature available the effect of neem oil, carbosulfan and Oxadiargyl on rice crop is very scanty hence the aim of this study was undertaken to evaluate the impacts of biocides on seed germination, seedling vigor and chlorophyll contents of 14 day's old seedlings.

\section{Materials and Methods}

Pure line seeds of above mentioned cultivars of rice were procured from Regional Agricultural Research Station, Odisha University of Agriculture and Technology (O.U.A.T), Brahmapur. Bio-pesticides i.e. neem oil, Carbosulfar 25\%E.C. (Marshal) and Topstar (Oxadiargy1 80\% w.p.) were used in this present piece of investigation.

\section{Preparation and mode of application of test chemicals}

The common recommended doses, of different concentrations of the test chemicals were prepared by using distilled water as solvent. In this piece of investigation, the preliminary concentrations $0.5,1.5,2.0,2.5,3.0,3.5,4.0$,
$4.5,5.0 \mathrm{ml} / \mathrm{l}$ or $\mathrm{gm} / \mathrm{kg}$ of all the bio-pesticides i.e. Neem oil, carbosulfan $25 \%$ E.C. (Marshal) and Topstar (oxadiargy1 $80 \%$ W.P.) were prepared.

\section{Experimental schedule}

Seed germination and seedling growth experiments of test plant were conducted in the laboratory condition and study the vegetative growth parameters and chlorophyll contents.

\section{Methodology}

\section{Surface Sterilization}

All the glass wares including seeds have been properly sterilized. Prior to germination, all the seeds were surface sterilized by treating with $5 \%$ concentration of sodium hypochloride solution for 12 minutes and then thoroughly washing it with distilled water for 3 to 4 times to remove completely the sodium hypo-chloride solution. Glass materials, absorbent cotton, filter papers and vermiculites were properly sterilized and used for germination of test plant rice seeds.

\section{Germination bed}

Clear and sterilized petridishes were divided into triplicate for each concentration of test chemical and control for experimental purpose. Ten $\mathrm{ml}$ of different concentrations of neem oil, carbosulfan 25\% E.C. (Marshal) and Topstar (oxadiargyl 80\% W.P.) i.e. 0.5, 1.0, $1.5,2.0,2.5,3.0,3.5,4.0,4.5,5.0 \mathrm{ml} / 1$ were applied to different petridishes $(10 \mathrm{~cm}$ in size)@ 50 test plant seeds per dish lined with blotting paper.

Control set of petridishes were prepared by taking same amount of water. Watering was allowed in all petridishes at an interval of 12 hr with $10 \mathrm{ml}$ of water. 


\section{Germination chamber}

Specially designed germination chamber was meant to study the vigoursity of germination of test seeds under different pesticides i.e. treatment with scheduled concentration of test pesticides. Light is an inhibitory factor for the process of the germination, hence precaution were taken to make the germination chamber light proof throughout the course of investigation.

The duration of germination experiment limited to $72 \mathrm{hr}$. for first observation of germination was recorded after $12 \mathrm{hr}$. treatment and subsequently at an interval 12 hr. duration the germination strategy of scheduled i.e. $72 \mathrm{hr}$. Emergence of radical through the coleoptiles extending the length of $0.1 \mathrm{~cm}$ was considered as the standard of germination.

\section{Seedling Chamber}

A special type of chamber has been designed for the growth of germination seed designated as seedling chamber. The chamber is partitioned by wooden plates to keep the petridishes. Besides maintaining of thermostability, Photo-stability has been allowed with $2000 \pm 200$ lux of fluorescent light throughout the course of seedling growth. Temperature constancy maintained at $25^{\circ} \mathrm{C}$ during the course of seedling growth investigations.

Petridishes with germination seeds were transferred to the seedling chamber. Growth of radical and plumule of the germinating seeds were allowed for seven days.

Throughout the period of seedling growth aeration under the laboratory conditions was kept intact. Random collection of days old seedlings was made from the seedling chamber for the different vegetative parameters and chlorophyll content.
The collected seedlings were washed properly with water and separated root and shoot portion. The separated shoot and root portions were soaked with blotting paper and measured length and fresh weight. The shoot and root were dried in a woven with $60^{\circ}$ centigrade and measured dry weight.

\section{Extraction and estimation of chlorophyll}

In order to measure the chlorophyll content in leaves, ten seedlings of 14 days old were taken randomly from each petridish of both control and treated a sets, leaves were separated from seedlings, washed thoroughly, dried the surface water by soaking on a blotting paper, cut in to small pieces and weighted for $50 \mathrm{mg}$. then this weighted samples were homogenized with 1-2 ml. of $80 \%$ ethanol(v/v) with mortar and pestle and the homogenate were centrifuged at $3000 \mathrm{xg}$ for 20 minutes at $28 \pm$ $10 \mathrm{c}$.

The pellets were again homogenized with $80 \%$ ethanol and centrifugation was repeated till colorless pellets obtained which were further used for other chemical analysis. All the supernatants were pooled together and a total volume of $10 \mathrm{ml}$. was prepared with $80 \%$ ethanol. The optical density (O.D) of the extract was measured with help of Elico digital spectrophotometer (model CL-27) at 663 and $645 \mathrm{~nm}$, taking $80 \%$ ethanol as blank. Estimations were calculated following the formulae suggested by Arnon (1949).

$$
\begin{aligned}
& \text { Total } \\
& =\frac{20.2 \times(O . D . a t 645 \mathrm{~nm})+8.02 \times(O . D . a t 663 \mathrm{~nm})}{1000 \times \mathrm{W}} \times \\
& \mathrm{v} \mathrm{mg} / \mathrm{g} \text { (fresh weight) }
\end{aligned}
$$

Where,

$\mathrm{V}=$ Total volume of extract in C.C

$\mathrm{W}=$ Weight of samples in gram

And O.D. = Optical density of the extract 


\section{Results and Discussion}

\section{Seed germination}

\section{Effect of neem oil}

Treatment of Paddy seeds was done in the germination bed containing $0.5,1.0,1.5,2.0$, 2.5, 3.0, 3.5, 4.0, 4.5, 5.0ml./lit and controlled set. The time of exposure for germination of seeds was allowed for $24 \mathrm{~h}, 36 \mathrm{~h}, 48 \mathrm{~h}, 60 \mathrm{~h}$ and $72 \mathrm{~h}$. Rate of germination of rice seeds with respect to time of treatment in different concentration of neem oil and controlled condition was studied. After an interval of $24 \mathrm{~h}$ the first observation were made. The highest rate of germination percentage was found in the controlled condition comparing with test chemicals. The rate of germination percentage in rice seeds progressively declined with the increasing concentration of neem oil. Thus the percentage of germination is considered to be inversely proportional to the concentration of neem oil treatment. Under controlled condition percentage of germination was found to be $27.2 \%$ subsequently $25.27,23.2 \%$, $20.3 \%, 17.9 \%, 16 \%, 14.2 \%, 12.3 \%, 10.3 \%$, $7.6 \%$ and $3.4 \%$ of seed germination were observed with the treatment of $0.5,1.0,1.5$, 2.0, 2.5, 3.0, 3.5, 4.0, 4.5 and 5.0ml./lit concentration of neem oil respectively after 24 $\mathrm{h}$ incubation. Percentage of seeds germination after $72 \mathrm{~h}$ were $97.4 \%$ in control and $87.8 \%$, $78.2 \%, 63.2 \%, 58.5 \%, 44.8 \%, 36.4 \%, 32 \%$, $22.9 \%, 16.4 \%$ and $8.2 \%$ in $0.5,1.0,1.5,2.0$, $2.5, \quad 3.0, \quad 3.5, \quad 4.0, \quad 4.5$ and $5.0 \mathrm{ml} . / \mathrm{lit}$ concentration of neem oil respectively. Other concentration exhibited intermediate value (Table 1).

The correlation coefficient values were calculating between the concentration of neem oil and percentage of germination of the different duration of observation. Significance values (p) were also calculated taking degree of freedom (df) for the different hours of treatment. The $\mathrm{r}$ values were after $24 \mathrm{~h} . \mathrm{r}=$ 0.974 and the value of $p \leq 0.001$, after $36 \mathrm{~h}$ the value of $r=-0.967$ and $p \leq 0.001$, after $48 h$. $r=$ -0.962 and $\mathrm{p} \leq 0.001$, after $60 \mathrm{~h} \mathrm{r}=-0.985$ and $\mathrm{p} \leq 0.001$ and after $72 \mathrm{~h} . \mathrm{r}=-0.954$ and $\mathrm{p} \leq 0.001$ (Table 1).

\section{Effect of Carbosulfan 25\% E.C.}

Paddy seeds were done in the germination bed containing $0.5,1.0,1.5,2.0,2.5,3.0,3.5,4.0$, $4.5,5.0 \mathrm{ml} . /$ lit. and controlled set. The rate of germination percentage in rice seeds progressively declined with the increasing concentration of Carbosulfan $25 \%$ E C. (Marshal). Thus the percentage of germination is considered to be inversely proportional to the concentration of Carbosulfan 25\% E.C. (Marshal) treatment. However with the increase in time period of observation the rate of germination percentage gradually increased. After $24 \mathrm{~h}$ of interval under controlled conditions percentage of germination was found to be $27.2 \%$ subsequently $23.8 \%, 21 \%, 16.8 \%, 15.4 \%$, $11 \%, 10.5 \%, 8.7 \%, 7.4 \%, 5.4 \%$ and $2.2 \%$ of seed germination were observed with the treatment of $0.5,1.0,1.5,2.0,2.5,3.0,3.5$, 4.0, 4.5 and $5.0 \mathrm{ml}$./lit. concentration of Carbosulfan 25\% E.C. (Marshal) respectively. Maximum germination of seeds were observed after $72 \mathrm{~h}$ of treatment in $1.0,1.5$, 2.0, 2.5, 3.0, 3.5, 4.0, 4.5 and 5.0ml./lit concentration of Carbosulfan $25 \%$ E.C. (Marshal) and controlled set condition the seeds were found germinated in the order of $84.1 \%, 75.4 \%, 60.5 \%, 55.8 \%, 40.7 \%, 32.4 \%$, $28.7 \%, 21.5 \%, 13.8 \%, 6.9 \%$ and $97.4 \%$, respectively. Treatment with other concentration of Carbosulfan $25 \%$ E.C. (Marshal) observed intermediate values (Table 2).

The correlation coefficient values were calculating between the concentration of Carbosulfan $25 \%$ E.C. (Marshal) and 
percentage of germination of the different duration of observation. Significance values (p) were also calculated taking degree of freedom (df) for the different hours of treatment. Thus after $24 \mathrm{~h} . \mathrm{r}=-0.985$ and the value of $p \leq 0.001$, after $36 \mathrm{~h}$ the value of $\mathrm{r}=$ 0.978 and $\mathrm{p} \leq 0.001$, after $48 \mathrm{~h} . \mathrm{r}=-0.972$ and $\mathrm{p} \leq 0.001$, after $60 \mathrm{~h} \mathrm{r}=-0.969$ and $\mathrm{p} \leq 0.001$ and after $72 \mathrm{~h}$. $\mathrm{r}=-0.959$ and $\mathrm{p} \leq 0.001$.

\section{Effect of Topstar (Oxadiargyl 80\% W.P.)}

The rate of germination percentage in rice seeds progressively declined with the increasing concentration of Topstar (Oxadiargyl 80\% W.P.) and the percentage of germination is considered to be inversely proportional to the concentration of Topstar (Oxadiargyl $80 \%$ W.P.) treatment. However with the increase in time period of observation the rate of germination percentage gradually increased. After $24 \mathrm{~h}$ of interval under controlled conditions percentage of germination was found to be $27.2 \%$ subsequently $22.6 \%, 17.8 \%, 16.4 \%, 14.9 \%$, $10.7 \%, 10.3 \%, 8.5 \%, 7.2 \%, 5.1 \%$ and $1.8 \%$ of seed germination were observed with the treatment of $0.5,1.0,1.5,2.0,2.5,3.0,3.5$, 4.0, 4.5 and $5.0 \mathrm{ml} . /$ lit. Concentration of Top star (Oxadiargyl $80 \%$ W.P.) respectively. Percentage of germination of seeds after $72 \mathrm{~h}$ of treatment in controlled condition, 1.0, 1.5, 2.0, 2.5, 3.0, 3.5, 4.0, 4.5 and 5.0ml./lit concentration of Topstar (Oxadiargyl 80\% W.P.) were found in the order of $97.4 \%$, $83.2 \%, 71.2 \%, 60.4 \%, 53.7 \%, 40.5 \%, 32.2 \%$, $27.9 \%, 21.7 \%, 12.8 \%$ and $6.8 \%$ respectively (Table 3).

The correlation coefficient values were calculating between the concentration of $\begin{array}{lll}\text { Topstar (Oxadiargyl } 80 \% & \text { W.P.) and }\end{array}$ percentage of germination of the different duration of observation. Significance values (p) were also calculated taking degree of freedom (df) for the different hours of treatment. Thus after $24 \mathrm{~h} . \mathrm{r}=-0.988$ and the value of $\mathrm{p} \leq 0.001$, after $36 \mathrm{~h}$ the value of $\mathrm{r}=$ 0.982 and $\mathrm{p} \leq 0.001$, after $48 \mathrm{~h}$. $\mathrm{r}=-0.975$ and $\mathrm{p} \leq 0.001$, after $60 \mathrm{~h} \mathrm{r}=-0.970$ and $\mathrm{p} \leq 0.001$ and after $72 \mathrm{~h}$. $\mathrm{r}=-0.962$ and $\mathrm{p} \leq 0.001$.

\section{Vegetative growth (Root and Shoot length)}

\section{Effect of neem oil}

All the concentration of neem oil considerably checked the root length of rice seedling. The seedling of control set exhibited maximum length of root $4.1 \pm 0.02 \mathrm{~cm}$ at 14 days. The maximum root length of rice seedling exhibited the length of $3.8 \pm 0.01 \mathrm{~cm}$ with treatment of $0.5 \mathrm{ml}$./lit. concentration at 14 days however minimum root growths $1.2 \pm$ $0.01 \mathrm{~cm}$ in 14 days old rice seedlings were found in treatment with $5 \mathrm{ml}$./lit. concentration of neem oil. Statistical methods for mean length of root growth \pm standard deviation adopted taking 100 random samples in each case, value of $r$ found -0.975 at 14 days old rice seedling and at $\mathrm{p} \leq 0.001$ obtained with d.f. 20. Shoot length exhibited more or less same trean as it found in root length and their values The seedling of control set exhibited maximum length of root $8.4 \pm 0.04 \mathrm{~cm}$ at 14 days however the shoot length of rice seedling exhibited the length of $7.9 \pm 0.03 \mathrm{~cm}$ and $2.7 \pm$ $0.01 \mathrm{~cm}$ in 14 days old rice seedlings treated with 0.5 and $5.0 \mathrm{ml}$./lit. concentration of neem oil respectively. Statistical methods for mean length of shoot growth \pm standard deviation adopted taking 100 random samples in each case, value of $r$ found -0.981 at 14 days old rice seedling. However, $\mathrm{p} \leq 0.001$ obtained with d.f. 20 (Table 4).

\section{Effect of carbosulfan $25 \%$ E.C. (Marshal)}

Carbosulfan 25\% E.C. (Marshal) checked the root length of rice seedling at all the concentration ranging from 0.5 to $5.0 \mathrm{ml} / \mathrm{l}$. The seedling of control set exhibited 
maximum length of root $4.1 \pm 0.02 \mathrm{~cm}$ whereas minimum root growths $0.6 \pm 0.01 \mathrm{~cm}$ in 14 days old rice seedlings treated with 5 ml./lit. concentration of carbosulfan $25 \%$ E.C. (Marshal).Statistical methods for mean length of root growth \pm standard deviation adopted taking 100 random samples in each case, value of $r$ found -0.958 at 14 days old rice seedling and at $p \leq 0.001$ obtained with d.f. 20. The shoot length of seedling of control set exhibited maximum length of shoot $8.4 \pm 0.04$ $\mathrm{cm}$ at 14 days whereas the shoot length of rice seedling exhibited the length of $7.1 \pm 0.03 \mathrm{~cm}$ and $8.5 \pm 0.01 \mathrm{~cm}$ in 14 days old rice seedlings with treatment of $0.5 \mathrm{Ml}$./lit. and 5 $\mathrm{ml}$./lit. concentration of carbosulfan $25 \%$ E.C. (Marshal) respectively. Statistical methods for mean length of shoot growth \pm standard deviation adopted taking 100 random samples in each case, value of $\mathrm{r}$ found -0.961 at 14 days old rice seedling at $\mathrm{p} \leq 0.001$ obtained with d.f. 20(Table 5).

\section{Effect of Topstar (oxadiargyl 80\% W.P.)}

All the concentration of Topstar (oxadiargyl $80 \%$ W.P.) considerably checked the root length of rice seedling. The seedling of control set exhibited maximum length of root $4.1 \pm$ $0.02 \mathrm{~cm}$ at 14 days however at same period of incubation the root length of rice seedling exhibited the length of $2.9 \pm 0.01 \mathrm{~cm}$ with treatment of $0.5 \mathrm{ml} . / \mathrm{lit}$. and $0.6 \pm 0.01 \mathrm{~cm}$ in treatment with $5 \mathrm{ml}$./lit. concentration of Topstar (oxadiargyl 80\% W.P.). Statistical methods for mean length of root growth \pm standard deviation adopted taking 100 random samples in each case, value of $r$ found -0.957 at 14 days old rice seedling at $\mathrm{p} \leq 0.001$ obtained with d.f. 20. The effect of Topstar (oxadiargyl $80 \%$ W.P.) on shoot length exhibited similar trend as it found in Carbosulfan 25\% E.C. The seedling of control set exhibited maximum length of shoot $8.4 \pm$ $0.04 \mathrm{~cm}$ at 14 days however the shoot length of rice seedling exhibited the length of $6.9 \pm$
$0.03 \mathrm{~cm}$ and $1.3 \pm 0.01 \mathrm{~cm}$ in 14 days old rice seedlings treated with $0.5 \mathrm{Ml}$./lit. and $5 \mathrm{ml} . / \mathrm{lit}$. concentration of Topstar (oxadiargyl $80 \%$ W.P.) respectively. Statistical methods for mean length of shoot growth \pm standard deviation adopted taking 100 random samples in each case, value of $r$ found -0.966 at 14 days old rice seedling at $\mathrm{p} \leq 0.001$ obtained with d.f. 20 (Table 6).

\section{Fresh and dry weight (Shoot and root) of rice seedlings}

\section{Effect of neem oil}

All the concentration of neem oil considerably checked the shoot fresh weight of rice seedling. The seedling of control set exhibited maximum fresh weight $13.8 \pm 0.12 \mathrm{mg}$ at 14 days however the shoot fresh weight of rice seedling exhibited the length of $12.0 \pm 0.11 \mathrm{mg}$ and $4.7 \pm 0.02 \mathrm{mg}$ in 14 days old rice seedlings treated with $0.5 \mathrm{ml}$./lit. and $5 \mathrm{ml} / \mathrm{lit}$. concentration of neem oil respectively. The seedling of control set exhibited maximum shoot dry weight $4.1 \pm 0.04 \mathrm{mg}$ at 14 days whereas the shoot dry weight of rice seedling exhibited the length of $3.3 \pm 0.06 \mathrm{mg}$ and $1.4 \pm$ $0.02 \mathrm{mg}$ in 14 days old rice seedlings treated with $0.5 \mathrm{ml} . /$ lit. and $5 \mathrm{ml}$./lit concentrations of neem oil respectively.

All the concentration of neem oil considerably checked the root fresh weight of rice seedling. The seedling of control set exhibited maximum root fresh weight $7.2 \pm 0.06 \mathrm{mg}$ at 14 days. However the root fresh weight of rice seedling exhibited $6.7 \pm 0.05 \mathrm{mg}$ and $3.1 \pm$ $0.02 \mathrm{mg}$ in 14 days old rice seedlings treated with $0.5 \mathrm{ml}$./lit. and $5 \mathrm{ml} / \mathrm{lit}$. concentration of neem oil respectively. The seedling of control set exhibited maximum root dry weight $2.7 \pm$ $0.05 \mathrm{mg}$ at 14 days. However the root dry weight of rice seedling exhibited the length of $2.1 \pm 0.04 \mathrm{mg}$ with treatment of $0.5 \mathrm{Ml} . /$ lit. concentration of neem oil at 14 days. Similarly 
root dry weight $0.8 \pm 0.01 \mathrm{mg}$ in 14 days old rice seedlings were found in treatment with 5 Ml./lit. concentration of neem oil (Table 4).

\section{Effect of Carbosulfan 25\% E.C. (Marshal)}

All the concentration of carbosulfan $25 \%$ E.C. (Marshal) considerably checked the shoot fresh weight of rice seedling. The seedling of control set exhibited maximum fresh weight $13.8 \pm 0.12 \mathrm{mg}$ at 14 days. However the shoot fresh weight of rice seedling exhibited the length of $9.5 \pm 0.08 \mathrm{mg}$ with treatment of 0.5 $\mathrm{ml} / \mathrm{lit}$. concentration of carbosulfan $25 \%$ E.C.(Marshal)at 14 days. Shoot fresh weight $3.4 \pm 0.01 \mathrm{mg}$ in 14 days old rice seedlings were found in treatment with $5 \mathrm{ml}$./lit. concentration of carbosulfan $25 \%$ E.C.(Marshal). The seedling of control set exhibited maximum dry weight $4.1 \pm 0.04 \mathrm{mg}$ at 14 days. However the shoot dry weight of rice seedling exhibited the length of $2.8 \pm 0.05$ $\mathrm{mg}$ with treatment of $0.5 \mathrm{ml} . / \mathrm{lit}$. concentration of carbosulfan 25\% E.C.(Marshal)at 14 days. Similarly shoot dry weight $0.8 \pm 0.01 \mathrm{mg}$ in 14 days old rice seedlings were found in treatment with $5 \mathrm{Ml}$./lit. concentration of carbosulfan $25 \%$ E.C.(Marshal).

Carbosulfan 25\% E.C. (Marshal) considerably checked the root fresh weight of rice seedling at all treated concentration. The seedling of control set exhibited maximum root fresh weight $7.2 \pm 0.06 \mathrm{mg}$ at 14 days. However the root fresh weight of rice seedling exhibited the length of $5.8 \pm 0.04 \mathrm{mg}$ with treatment of 0.5 ml./lit. concentration of carbosulfan 25\% E.C.(Marshal) at 14 days. The root fresh weight $2.3 \pm 0.01 \mathrm{mg}$ in 14 days old rice seedlings were found in treatment with 5 ml./lit. concentration of carbosulfan $25 \%$ E.C.(Marshal). The seedling of control set exhibited maximum root dry weight $2.7 \pm 0.05$ $\mathrm{mg}$ at 14 days. However the root dry weight of rice seedling exhibited $1.6 \pm 0.03 \mathrm{mg}$ with treatment of $0.5 \mathrm{ml}$./lit. concentration of carbosulfan 25\% E.C.(Marshal) at 14 days. The root dry weight $0.2 \pm 0.01 \mathrm{mg}$ in 14 days old rice seedlings were found in treatment with $5 \mathrm{ml}$./lit. concentration of carbosulfan 25\% E.C.(Marshal) (Table 5).

\section{Effect of Topstar (Oxdiargyl 80\% W.P.)}

All the concentration of Topstar (Oxadiargyl $80 \%$ W.P.) considerably checked the shoot fresh weight of rice seedling. The seedling of control set exhibited maximum fresh weight $13.8 \pm 0.12 \mathrm{mg}$ at 14 days. However the shoot fresh weight of rice seedling exhibited the length of $9.3 \pm 0.08 \mathrm{mg}$ with treatment of 0.5 Ml./lit. concentration of Topstar (Oxadiargyl $80 \%$ W.P.) at 14 days. The shoot fresh weight $3.0 \pm 0.01 \mathrm{mg}$ in 14 days old rice seedlings were found in treatment with $5 \mathrm{Ml} . / \mathrm{lit}$. concentration of Topstar (Oxadiargyl 80\% W.P.).

The seedling of control set exhibited maximum dry weight $4.1 \pm 0.04 \mathrm{mg}$ at 14 days. However the shoot dry weight of rice seedling exhibited the length of $2.6 \pm 0.05 \mathrm{mg}$ with treatment of $0.5 \mathrm{ml}$./lit. concentration of Topstar (Oxadiargyl 80\% W.P.) at 14 days. The shoot dry weight $0.6 \pm 0.01 \mathrm{mg}$ in 14 days old rice seedlings were found in treatment with $5 \mathrm{Ml} . /$ lit. concentration of Topstar (Oxadiargyl 80\% W.P.)

Different concentrations of Topstar (Oxadiargyl 80\% W.P.) considerably checked the root fresh weight of rice seedling. The seedling of control set exhibited maximum root fresh weight $7.2 \pm 0.06 \mathrm{mg}$ at 14 days. However the root fresh weight of rice seedling exhibited the length of $5.6 \pm 0.04 \mathrm{mg}$ with treatment of $0.5 \mathrm{ml} . /$ lit. concentration of Topstar (Oxadiargyl 80\% W.P.) at 14 days. The root fresh weight $2.2 \pm 0.01 \mathrm{mg}$ in 14 days old rice seedlings were found in treatment with $5 \mathrm{ml} . /$ lit. concentration of Topstar (Oxadiargyl 80\% W.P.) The seedling 
of control set exhibited maximum root dry weight $2.7 \pm 0.05 \mathrm{mg}$ at 14 days. However the root dry weight of rice seedling exhibited the length of $1.4 \pm 0.02 \mathrm{mg}$ with treatment of 0.5 ml./lit. concentration of Topstar (Oxadiargyl $80 \%$ W.P.) at 14 days. The root dry weight $0.25 \pm 0.01 \mathrm{mg}$ in 14 days old rice seedlings were found in treatment with $5 \mathrm{ml} . / \mathrm{lit}$. concentration of Topstar (Oxadiargyl 80\% W.P.) (Table 6).

\section{Chorophyll contents in rice seedlings}

\section{Effect of neem oil}

The different concentrations of neem oil considerably checked the chlorophyll contents of rice seedling. The seedling of control set exhibited maximum chlorophyll - a contents $3.04 \pm 0.06 \mathrm{mg}$ at 14 days. However the chlorophyll - a contents of rice seedling exhibited $2.68 \pm 0.06 \mathrm{mg}$ with treatment of 0.5 $\mathrm{ml} . /$ lit. concentration of neem oil at 14 days. The chlorophyll - a contents $0.89 \pm 0.02 \mathrm{mg}$ in 14 days old rice seedlings were found in treatment with $5 \mathrm{ml}$./lit. concentration of neem oil.

The seedling of control set exhibited maximum chlorophyll - b contents $0.89 \pm 0.02$ $\mathrm{mg}$ at 14 days. However the chlorophyll - b contents of rice seedling exhibited the length of $0.83 \pm 0.02 \mathrm{mg}$ with treatment of $0.5 \mathrm{ml}$./lit. concentration of neem oil at 14 days. The chlorophyll-b contents $0.37 \pm 0.01 \mathrm{mg}$ in 14 days old rice seedlings were found in treatment with $5 \mathrm{ml}$./lit. concentration of neem oil.

The seedling of control set exhibited maximum total chlorophyll contents $3.93 \pm$ $0.09 \mathrm{mg}$ at 14 days. However the total chlorophyll contents of rice seedling exhibited the length of $3.51 \pm 0.08 \mathrm{mg}$ with treatment of $0.5 \mathrm{ml} . /$ lit. concentration of neem oil at 14 days. Total chlorophyll contents $1.26 \pm 0.03$ $\mathrm{mg}$ in 14 days old rice seedlings were found in treatment with $5 \mathrm{ml}$./lit. concentration of neem oil (Table 4).

\section{Effect of Carbosulfan 25\% E.C. (Marshal)}

All the concentration of Carbosulfan 25\% E.C. (Marshal) considerably checked the chlorophyll contents of rice seedlings. The seedling of control set exhibited maximum chlorophyll - a contents $3.04 \pm 0.06 \mathrm{mg}$ at 14 days. However the chlorophyll - a contents of rice seedling exhibited the length of $2.46 \pm$ $0.05 \mathrm{mg}$ with treatment of $0.5 \mathrm{Ml} . / \mathrm{lit}$. concentration of Carbosulfan 25\% E.C. (Marshal) at 14 days. Chlorophyll - a contents $0.76 \pm 0.02 \mathrm{mg}$ in 14 days old rice seedlings were found in treatment with $5 \mathrm{Ml}$./lit. concentration of Carbosulfan $25 \%$ E.C. (Marshal).

The seedling of control set exhibited maximum chlorophyll- b contents $0.89 \pm 0.02$ $\mathrm{mg}$ at 14 days.

However the chlorophyll - $\mathrm{b}$ contents of rice seedling exhibited $0.68 \pm 0.02 \mathrm{mg}$ with treatment of $0.5 \mathrm{Ml}$./lit. concentration of Carbosulfan $25 \%$ E.C. (Marshal) at 14 days. The chlorophyll-b contents $0.27 \pm 0.01 \mathrm{mg}$ in 14 days old rice seedlings were found in treatment with $5 \mathrm{Ml}$./lit. concentration of Carbosulfan 25\% E.C. (Marshal).

The seedling of control set exhibited maximum total chlorophyll contents $3.93 \pm$ $0.09 \mathrm{mg}$ at 14 days. However the total chlorophyll contents of rice seedling exhibited $3.14 \pm 0.07 \mathrm{mg}$ with treatment of $0.5 \mathrm{Ml}$./lit. concentration of Carbosulfan $25 \%$ E.C. (Marshal) at 14 days.

Total chlorophyll contents $1.03 \pm 0.02 \mathrm{mg}$ in 14 days old rice seedlings were found in treatment with $5 \mathrm{Ml} . /$ lit. concentration of Carbosulfan 25\% E.C. (Marshal) (Table 5). 
Table.1 Germination Potency of Oryza sativa var. IR-36 at different concentration of neem oil. Correlation coefficient ${ }^{\circledR}$ values are calculated between concentration of neem oil and percentage of germination.

Significance (p) values are shown in parentheses with d.f. 20

\begin{tabular}{|c|c|c|c|c|c|c|c|c|c|c|c|c|c|}
\hline \multirow{2}{*}{$\begin{array}{l}\text { Concentration of } \\
\text { test chemical } \\
\mathrm{ml} / \text { lit. }\end{array}$} & \multirow{2}{*}{$\begin{array}{c}\text { No of seeds } \\
\text { taken }\end{array}$} & \multirow{2}{*}{$\begin{array}{l}\text { thermo } \\
\text { constancy }\end{array}$} & \multicolumn{5}{|c|}{ No of seeds germinated at } & \multicolumn{5}{|c|}{ Percentage of germination } & \multirow{2}{*}{$\begin{array}{c}\text { Correlation } \\
\text { coefficient }(\mathrm{v}) \text { with } \\
\text { level of significance } \\
\text { ( } \mathrm{p} \text { value) of } \\
\text { percentage of } \\
\text { germination }\end{array}$} \\
\hline & & & $24 \mathrm{~h}$ & $26 h$ & $48 \mathrm{~h}$ & $60 \mathrm{~h}$ & $72 h$ & $24 \mathrm{~h}$ & $36 h$ & $48 \mathrm{~h}$ & $60 \mathrm{~h}$ & $72 \mathrm{~h}$ & \\
\hline Control & 1000 & 28 & 272 & 458 & 712 & 882 & 974 & 27.20 & 45.80 & 71.20 & 88.20 & 97.40 & \multirow[t]{2}{*}{$24 \mathrm{~h} \mathrm{r}=0.974(\mathrm{p} \leq 0.001)$} \\
\hline 0.5 & 1000 & 28 & 252 & 412 & 624 & 803 & 878 & 25.20 & 41.20 & 62.40 & 80.30 & 87.80 & \\
\hline 1.0 & 1000 & 28 & 232 & 403 & 529 & 704 & 782 & 23.20 & 40.30 & 52.90 & 70.40 & 78.20 & \multirow{2}{*}{$\begin{array}{c}36 h r=-0.967 \\
(p \leq 0.001)\end{array}$} \\
\hline 1.5 & 1000 & 28 & 203 & 374 & 465 & 603 & 632 & 20.30 & 37.40 & 46.50 & 60.30 & 63.20 & \\
\hline 2.0 & 1000 & 28 & 179 & 312 & 346 & 523 & 585 & 17.90 & 31.20 & 34.60 & 52.30 & 58.50 & \multirow{2}{*}{$\begin{array}{c}48 \mathrm{~h} r=0.962 \\
(\mathrm{p} \leq 0.001)\end{array}$} \\
\hline 2.5 & 1000 & 28 & 160 & 278 & 302 & 413 & 448 & 16.00 & 27.80 & 30.20 & 41.30 & 44.80 & \\
\hline 3.0 & 1000 & 28 & 142 & 208 & 250 & 336 & 364 & 14.20 & 20.80 & 25.00 & 33.60 & 36.40 & \multirow{2}{*}{$\begin{array}{c}60 h \mathrm{r}=0.958 \\
(\mathrm{p} \leq 0.001)\end{array}$} \\
\hline 3.5 & 1000 & 28 & 123 & 168 & 206 & 246 & 320 & 12.30 & 16.80 & 20.60 & 24.60 & 32.00 & \\
\hline 4.0 & 1000 & 28 & 103 & 126 & 159 & 218 & 229 & 10.30 & 12.60 & 15.90 & 21.80 & 22.90 & \multirow{3}{*}{$\begin{array}{c}72 \mathrm{~h} \mathrm{r}=0.954 \\
(\mathrm{p} \leq 0.001)\end{array}$} \\
\hline 4.5 & 1000 & 28 & 76 & 98 & 122 & 134 & 164 & 7.60 & 9.80 & 12.20 & 13.40 & 16.40 & \\
\hline 5.0 & 1000 & 28 & 34 & 47 & 58 & 69 & 82 & 3.40 & 4.70 & 5.80 & 6.90 & 8.20 & \\
\hline
\end{tabular}


Table.2 Germination Potency of Oryza sativa var. IR-36 at different concentration of Carbosulfan 25\% E.C. (Marshal). Correlation coefficient (r) values are calculated between concentration of Carbosulfan $25 \%$ E.C. (Marshal) and percentage of germination. Significance (p) values are shown in parentheses with d.f. 20

\begin{tabular}{|c|c|c|c|c|c|c|c|c|c|c|c|c|c|}
\hline \multirow{2}{*}{$\begin{array}{c}\text { Concentration of } \\
\text { test chemical } \\
\text { ml/lit. }\end{array}$} & \multirow{2}{*}{$\begin{array}{c}\text { No of seeds } \\
\text { taken }\end{array}$} & \multirow{2}{*}{$\begin{array}{l}\text { thermo } \\
\text { constancy }\end{array}$} & \multicolumn{5}{|c|}{ No of seeds germinated at } & \multicolumn{5}{|c|}{ Percentage of germination } & \multirow{2}{*}{$\begin{array}{l}\text { Correlation coefficient (v) } \\
\text { with level of significance }(\mathrm{p} \\
\text { value) of percentage of } \\
\text { germination }\end{array}$} \\
\hline & & & $24 \mathrm{~h}$ & 458 & $48 \mathrm{~h}$ & $60 \mathrm{~h}$ & $72 \mathrm{~h}$ & $24 \mathrm{~h}$ & $36 \mathrm{~h}$ & $48 \mathrm{~h}$ & $60 \mathrm{~h}$ & $72 \mathrm{~h}$ & \\
\hline Control & 1000 & 28 & 272 & 402 & 712 & 882 & 974 & 27.20 & 45.80 & 71.20 & 88.20 & 97.40 & $24 \mathrm{~h} \mathrm{r}=0.985(\mathrm{p} \leq 0.001)$ \\
\hline 0.5 & 1000 & 28 & 238 & 389 & 591 & 765 & 841 & 23.80 & 40.20 & 59.10 & 76.50 & 84.10 & \\
\hline 1.0 & 1000 & 28 & 210 & 307 & 502 & 674 & 754 & 21.00 & 38.90 & 50.20 & 67.40 & 75.40 & $36 \mathrm{~h} r=-0.978(\mathrm{p} \leq 0.001)$ \\
\hline 1.5 & 1000 & 28 & 168 & 292 & 428 & 568 & 605 & 16.80 & 30.70 & 42.80 & 56.80 & 60.50 & \\
\hline 2.0 & 1000 & 28 & 154 & 241 & 326 & 503 & 558 & 15.40 & 29.20 & 32.60 & 50.30 & 55.80 & $48 \mathrm{~h} \mathrm{r}=0.972(\mathrm{p} \leq 0.001)$ \\
\hline 2.5 & 1000 & 28 & 110 & 128 & 258 & 378 & 407 & 11.00 & 24.10 & 25.80 & 37.80 & 40.70 & \\
\hline 3.0 & 1000 & 28 & 105 & 116 & 183 & 302 & 324 & 10.50 & 12.80 & 18.30 & 30.20 & 32.40 & $60 \mathrm{~h} \mathrm{r}=0.969(\mathrm{p} \leq 0.001)$ \\
\hline 3.5 & 1000 & 28 & 87 & 104 & 143 & 218 & 287 & 8.70 & 11.60 & 14.30 & 21.80 & 28.70 & \\
\hline 4.0 & 1000 & 28 & 74 & 75 & 126 & 202 & 215 & 7.40 & 10.40 & 12.60 & 20.20 & 21.50 & $72 \mathrm{~h} \mathrm{r}=0.959(\mathrm{p} \leq 0.001)$ \\
\hline 4.5 & 1000 & 28 & 54 & 75 & 88 & 114 & 138 & 5.40 & 7.50 & 8.80 & 11.40 & 13.80 & \\
\hline 5.0 & 1000 & 28 & 22 & 34 & 42 & 58 & 69 & 2.20 & 3.40 & 4.20 & 5.80 & 6.90 & \\
\hline
\end{tabular}


Table.3 Germination Potency of Oryza sativa var. IR-36 at different concentration of Topstar (Oxadiargyl 80 \% W.P.). Correlation coefficient (B) values are calculated between concentration of Topstar (Oxadiargyl $80 \%$ W.P.) and percentage of germination. Significance (p) values are shown in parentheses with d.f. 20.

\begin{tabular}{|c|c|c|c|c|c|c|c|c|c|c|c|c|c|}
\hline \multirow{2}{*}{$\begin{array}{l}\text { Concentration of } \\
\text { test chemical ml/lit. }\end{array}$} & \multirow{2}{*}{$\begin{array}{l}\text { No of } \\
\text { seeds } \\
\text { taken }\end{array}$} & \multirow{2}{*}{$\begin{array}{l}\text { thermo } \\
\text { constancy }\end{array}$} & \multicolumn{5}{|c|}{ No of seeds germinated at } & \multicolumn{5}{|c|}{ Percentage of germination } & \multirow{2}{*}{$\begin{array}{c}\text { Correlation } \\
\text { coefficient (v) } \\
\text { with level of } \\
\text { significance (p } \\
\text { value) of } \\
\text { percentage of } \\
\text { germination }\end{array}$} \\
\hline & & & $24 \mathrm{~h}$ & $36 \mathrm{~h}$ & $48 \mathrm{~h}$ & $60 \mathrm{~h}$ & $72 \mathrm{~h}$ & $24 \mathrm{~h}$ & $36 \mathrm{~h}$ & $48 \mathrm{~h}$ & $60 \mathrm{~h}$ & $72 \mathrm{~h}$ & \\
\hline Control & 1000 & 28 & 272 & 458 & 712 & 882 & 974 & 27.20 & 45.80 & 71.20 & 88.20 & 97.40 & \multirow[t]{2}{*}{$\begin{array}{c}24 \mathrm{~h} \mathrm{r}=- \\
0.988(\mathrm{p} \leq 0.001)\end{array}$} \\
\hline 0.5 & 1000 & 28 & 226 & 396 & 582 & 751 & 832 & 22.60 & 39.60 & 58.20 & 75.10 & 83.20 & \\
\hline 1.0 & 1000 & 28 & 178 & 319 & 453 & 594 & 712 & 17.80 & 31.90 & 45.30 & 59.40 & 71.20 & \multirow{2}{*}{$\begin{array}{c}36 h r=--0.982 \\
\quad(p \leq 0.001)\end{array}$} \\
\hline 1.5 & 1000 & 28 & 164 & 302 & 416 & 542 & 604 & 16.40 & 30.20 & 41.60 & 54.20 & 60.40 & \\
\hline 2.0 & 1000 & 28 & 149 & 287 & 321 & 498 & 537 & 14.90 & 28.70 & 32.10 & 49.80 & 53.70 & \multirow[t]{2}{*}{$\begin{array}{c}48 h \mathrm{r}=-0.975 \\
\quad(\mathrm{p} \leq 0.001)\end{array}$} \\
\hline 2.5 & 1000 & 28 & 107 & 236 & 252 & 374 & 405 & 10.70 & 23.60 & 25.20 & 37.40 & 40.50 & \\
\hline 3.0 & 1000 & 28 & 103 & 124 & 178 & 296 & 322 & 10.30 & 12.40 & 17.80 & 29.60 & 32.20 & \multirow{2}{*}{$\begin{array}{c}60 \mathrm{~h} r=-0.970 \\
(p \leq 0.001)\end{array}$} \\
\hline 3.5 & 1000 & 28 & 85 & 113 & 147 & 212 & 279 & 8.50 & 11.30 & 14.70 & 21.20 & 27.90 & \\
\hline 4.0 & 1000 & 28 & 72 & 101 & 131 & 205 & 217 & 7.20 & 10.10 & 13.10 & 20.50 & 21.70 & \multirow[t]{3}{*}{$\begin{array}{c}72 \mathrm{~h} \mathrm{r}=-0.962 \\
(\mathrm{p} \leq 0.001)\end{array}$} \\
\hline 4.5 & 1000 & 28 & 51 & 69 & 95 & 112 & 128 & 5.10 & 6.90 & 9.50 & 11.20 & 12.80 & \\
\hline 5.0 & 1000 & 28 & 18 & 28 & 46 & 57 & 68 & 1.80 & 2.80 & 4.60 & 5.70 & 6.80 & \\
\hline
\end{tabular}


Table.4 Effect of neem oil on vegitative parameters and chlorophyll content of Oryza sativa var. IR-36 on fourteen day old seedlings (Values are in mean \pm S.D. of ten samples)-correlation coefficient $(r)$ values are calculated between different concentration of neem oil and different parameter`s studied. Significance levels are shown (p) value in parentheses with d.f.20.

\begin{tabular}{|c|c|c|c|c|c|c|c|c|c|c|c|c|}
\hline$\frac{\text { Treatment }}{\text { (Ml/Lit)Pa }}$ & Control & 0.5 & 1.0 & 1.5 & 2.0 & 2.5 & 3.0 & 3.5 & 4.0 & 4.5 & 5.0 & $\begin{array}{c}\text { Correlation } \\
\text { coefficient } \\
\text { with level of } \\
\text { siginificance(p } \\
\text { value) }\end{array}$ \\
\hline $\begin{array}{l}\text { Shoot } \\
\text { length }(\mathrm{cm})\end{array}$ & $8.4 \pm 0.04$ & $7.9 \pm 0.03$ & $7.4 \pm 0.03$ & $6.8 \pm 0.03$ & $6.2 \pm 0.03$ & $\begin{array}{l}5.8 \pm 0 \\
02\end{array}$ & $5.2 \pm 0.02$ & $\begin{array}{l}4.8 \pm 0 . \\
02\end{array}$ & $4.3 \pm 0.02$ & $3.8 \pm 0.02$ & $2.7 \pm 0.01$ & $\begin{array}{l}r=0.981(P \leq 0.0 \\
01)\end{array}$ \\
\hline $\begin{array}{l}\text { Shoot } \\
\text { fresh } \\
\text { weight } \\
\text { (mg) } \\
\end{array}$ & $13.8+0.12$ & $12.0 \pm 0.11$ & $10.3 \pm 0.09$ & $9.5 \pm 0.08$ & $8.4 \pm 0.07$ & $\begin{array}{l}7.1 \pm 0 . \\
06\end{array}$ & $6.1 \pm 0.04$ & $\begin{array}{l}5.6 \pm 0 . \\
03\end{array}$ & $5.2 \pm 0.02$ & $5.0 \pm 0.02$ & $4.7 \pm 0.02$ & \\
\hline $\begin{array}{l}\text { Shoot dry } \\
\text { weight(mg }\end{array}$ & $4.1 \pm 0.07$ & $3.3 \pm 0.06$ & $3.1 \pm 0.06$ & $2.8 \pm 0.05$ & $2.3 \pm 0.04$ & $\begin{array}{l}2.2 \pm 0 . \\
04\end{array}$ & $2.0 \pm 0.03$ & $\begin{array}{l}1.9 \pm 0 . \\
03\end{array}$ & $1.7 \pm 0.02$ & $1.5 \pm 0.02$ & $1.4 \pm 0.02$ & \\
\hline $\begin{array}{l}\text { Root } \\
\text { length } \\
(\mathrm{cm}) \backslash \\
\end{array}$ & $4.1 \pm 0.02$ & $3.8 \pm 0.01$ & $3.4 \pm 0.01$ & $3.1 \pm 0.01$ & $2.9 \pm 0.01$ & $\begin{array}{l}2.6 \pm 0 . \\
01\end{array}$ & $2.4 \pm 0.01$ & $\begin{array}{l}2.2 \pm 0 \\
01\end{array}$ & $1.8 \pm 0.01$ & $1.5 \pm 0.01$ & $1.2 \pm 0.01$ & $\begin{array}{l}r=- \\
0.975(p \leq 0.001\end{array}$ \\
\hline $\begin{array}{l}\text { Root fresh } \\
\text { weight(mg } \\
\text { ) }\end{array}$ & $7.2 \pm 0.06$ & $6.7 \pm 0.05$ & $6.2 \pm 0.05$ & $5.7 \pm 0.04$ & $5.2 \pm 0.04$ & $\begin{array}{l}4.9 \pm 0 . \\
03\end{array}$ & $4.6 \pm 0.03$ & $\begin{array}{l}4.3 \pm 0 . \\
02\end{array}$ & $3.8 \pm 0.02$ & $3.5 \pm 0.02$ & $3.1 \pm 0.02$ & \\
\hline $\begin{array}{l}\text { Root dry } \\
\text { weight(mg } \\
\text { ) }\end{array}$ & $2.7 \pm 0.05$ & $2.01 \pm 0.04$ & $1.9 \pm 0.03$ & $1.7 \pm 0.03$ & $1.6 \pm 0.03$ & $\begin{array}{l}1.5 \pm 0 \\
03\end{array}$ & $1.3 \pm 0.02$ & $\begin{array}{l}1.2 \pm 0 \\
03\end{array}$ & $1.1 \pm 0.02$ & $0.9 \pm 0.01$ & $0.8 \pm 0.01$ & \\
\hline \multirow[t]{3}{*}{$\begin{array}{c}\text { Chlorophy } \\
\text { Il content } \\
\text { mg/g }\end{array}$} & $3.04 \pm 0.06$ & $2.68+0.06$ & $2.45 \pm 0.05$ & $2.27 \pm 0.05$ & $2.06 \pm 0.05$ & $\begin{array}{l}1.85 \pm \\
0.04\end{array}$ & $1.68 \pm 0.04$ & $\begin{array}{l}1.57 \pm 0 \\
.04\end{array}$ & $1.48 \pm 0.03$ & $1.07 \pm 0.03$ & $0.89 \pm 0.02$ & $\begin{array}{l}r=- \\
0.978(p \leq 0.001\end{array}$ \\
\hline & $0.89+0.02$ & $0.83 \pm 0.02$ & $0.78 \pm 0.02$ & $0.72 \pm 0.02$ & $0.68 \pm 0.02$ & $\begin{array}{l}0.63 \pm \\
0.02\end{array}$ & $0.57 \pm 0.02$ & $\begin{array}{l}0.45 \pm 0 \\
.02\end{array}$ & $0.47 \pm 0.02$ & $0.43 \pm 0.02$ & $0.37 \pm 0.01$ & $\begin{array}{l}r=- \\
0.967(p \leq 0.967 \\
(p \leq 001)\end{array}$ \\
\hline & $3.93 \pm 0.09$ & $3.51 \pm 0.08$ & $3.23 \pm 0.08$ & $2.99 \pm 0.07$ & $2.74 \pm 0.06$ & $\begin{array}{l}2.18 \pm \\
0.6\end{array}$ & $2.25 \pm 0.05$ & $\begin{array}{l}2.02 \pm 0 \\
.05\end{array}$ & $1.95 \pm 0.04$ & $1.50 \pm 0.04$ & $1.23 \pm 0.03$ & $\begin{array}{l}r=\leq 982 \\
(p \leq 0.001)\end{array}$ \\
\hline
\end{tabular}


Table.5 Effect of CARBOSULFAN $25 \%$ EC(MARSHAL) oil on vegitative parameters and chlorophyll content of Oryza sativa var. IR-36 on fourteen day old seedlings (Values are in mean \pm S.D. of ten samples)-correlation coefficient(r) values are calculated between different concentration of CARBOSULFAN 25\% EC(MARSHAL) and different parameter`s studied. Significance levels are shown (p) value in parentheses with d.f. 20

\begin{tabular}{|c|c|c|c|c|c|c|c|c|c|c|c|c|}
\hline$\frac{\text { Treatment(MI/Lit) }}{\text { Parameter`s }}$ & Control & 0.5 & 1.0 & 1.5 & 2.0 & 2.5 & 3.0 & 3.5 & 4.0 & 4.5 & 5.0 & $\begin{array}{l}\text { Correlation } \\
\text { coefficient with level } \\
\text { of siginificance( } \\
\text { value) }\end{array}$ \\
\hline Shoot length $(\mathrm{cm})$ & $8.4 \pm 0.04$ & $7.1 \pm 0.03$ & $6.6 \pm 0.03$ & $5.8 \pm 0.02$ & $5.4 \pm 0.02$ & $5.1 \pm 0.02$ & $4.6 \pm 0.02$ & $4.0 \pm 0.02$ & $3.5 \pm 0.02$ & $2.9 \pm 0.02$ & $1.5 \pm 0.01$ & $\mathrm{r}=-0.961(\mathrm{P} \leq 0.001)$ \\
\hline $\begin{array}{l}\text { Shoot dry } \\
\text { weight(mg) }\end{array}$ & $4.1 \pm 0.07$ & $2.8 \pm 0.05$ & $2.5 \pm 0.05$ & $2.3 \pm 0.05$ & $2.1 \pm 0.04$ & $1.8 \pm 0.03$ & $1.5 \pm 0.03$ & $1.2 \pm 0.02$ & $1.1 \pm 0.02$ & $1.0 \pm 0.01$ & $0.8 \pm 0.01$ & \\
\hline Root length $(\mathrm{cm}) \backslash$ & $4.1 \pm 0.02$ & $3.0 \pm 0.01$ & $2.8 \pm 0.01$ & $2.6 \pm 0.01$ & $2.3 \pm 0.01$ & $2.1 \pm 0.01$ & $1.9 \pm 0.01$ & $1.5 \pm 0.01$ & $1.3 \pm 0.01$ & $0.9 \pm 0.01$ & $0.6 \pm 0.01$ & $\mathrm{r}=--0.958(\mathrm{p} \leq 0.001)$ \\
\hline $\begin{array}{l}\text { Root fresh } \\
\text { weight(mg) }\end{array}$ & $7.2 \pm 0.06$ & $5.8 \pm 0.04$ & $5.2 \pm 0.04$ & $4.8 \pm 0.03$ & $4.4 \pm 0.03$ & $4.1 \pm 0.03$ & $3.7 \pm 0.02$ & $3.1 \pm 0.02$ & $2.8 \pm 0.01$ & $2.7 \pm 0.01$ & $2.3 \pm 0.01$ & \\
\hline $\begin{array}{l}\text { Root dry } \\
\text { weight(mg) }\end{array}$ & $2.7 \pm 0.05$ & $1.6 \pm 0.03$ & $1.4 \pm 0.02$ & $1.3 \pm 0.02$ & $1.2 \pm 0.02$ & $1.1 \pm 0.02$ & $0.8 \pm 0.01$ & $0.6 \pm 0.01$ & $0.4 \pm 0.01$ & $0.3 \pm 0.01$ & $0.2 \pm 0.01$ & \\
\hline \multirow{3}{*}{$\begin{array}{l}\text { Chlorophyll } \\
\text { content } \mathrm{mg} / \mathrm{g}\end{array}$} & $3.04 \pm 0.06$ & $2.46 \pm 0.05$ & $2.32 \pm 0.05$ & $2.12 \pm 0.05$ & $1.91 \pm 0.04$ & $1.72 \pm 0.04$ & $1.52 \pm 0.04$ & $1.42 \pm 0.03$ & $1.31 \pm 0.03$ & $0.92 \pm 0.02$ & $0.76 \pm 0.02$ & $\mathrm{r}=-0.953(\mathrm{p} \leq 0.001)$ \\
\hline & $0.89+0.02$ & $0.68 \pm 0.02$ & $0.64 \pm 0.02$ & $0.62 \pm 0.02$ & $0.58 \pm 0.02$ & $0.54 \pm 0.02$ & $0.49 \pm 0.02$ & $0.43 \pm 0.02$ & $0.38 \pm 0.01$ & $0.34 \pm 0.01$ & $0.27 \pm 0.01$ & $\mathrm{r}=-0.974(\mathrm{p} \leq 0.001)$ \\
\hline & $3.93 \pm 0.09$ & $3.14 \pm 0.07$ & $2.96 \pm 0.07$ & $2.74 \pm 0.06$ & $2.49 \pm 0.06$ & $2.26 \pm 0.05$ & $2.01 \pm 0.05$ & $1.85 \pm 0.04$ & $1.69 \pm 0.04$ & $1.26 \pm 0.03$ & $1.03 \pm 0.02$ & $\mathrm{r}=-0.958(\mathrm{p} \leq 0.001)$ \\
\hline
\end{tabular}


Table.6 Effect of Topstar (Oxadiargyl $80 \%$ W.P.) on vegitative parameters and chlorophyll content of Oryza sativa var. IR-36 on fourteen day old seedlings (Values are in mean \pm S.D. of ten samples)-correlation coefficient(r) values are calculated between different concentration of Topstar (Oxadiargyl $80 \%$ W.P.) and different parameter`s studied. Significance levels are shown (p) value in parentheses with d.f. 20

\begin{tabular}{|c|c|c|c|c|c|c|c|c|c|c|c|c|}
\hline$\underline{\text { Treatment(MI/Lit) }}$ Parameter`s & Control & 0.5 & 1.0 & 1.5 & 2.0 & 2.5 & 3.0 & 3.5 & 4.0 & 4.5 & 5.0 & $\begin{array}{l}\text { Correlation coefficient } \\
\text { with level of } \\
\text { siginificance( } p \text { value) }\end{array}$ \\
\hline Shoot length $(\mathrm{cm})$ & $8.4 \pm 0.04$ & $6.9 \pm 0.03$ & $6.4 \pm 0.03$ & $5.3 \pm 0.02$ & $5.1 \pm 0.02$ & $4.9 \pm 0.02$ & $4.3 \pm 0.02$ & $3.8 \pm 0.02$ & $3.2 \pm 0.02$ & $2.6 \pm 0.02$ & $1.3 \pm 0.01$ & $\mathrm{r}=-0.966(\mathrm{P} \leq 0.001)$ \\
\hline Shoot fresh weight (mg) & $13.8+0.12$ & $9.3 \pm 0.08$ & $8.2 \pm 0.07$ & $7.6 \pm 0.06$ & $7.1 \pm 0.06$ & $5.6 \pm 0.06$ & $5.0 \pm 0.03$ & $4.5 \pm 0.02$ & $3.8 \pm 0.01$ & $3.4 \pm 0.01$ & $3.0 \pm 0.01$ & \\
\hline Shoot dry weight(mg) & $4.1 \pm 0.07$ & $2.6 \pm 0.05$ & $2.4 \pm 0.05$ & $2.1 \pm 0.04$ & $1.9 \pm 0.03$ & $1.7 \pm 0.03$ & $1.3 \pm 0.02$ & $1.1 \pm 0.02$ & $1.0 \pm 0.01$ & $0.8 \pm 0.01$ & $0.6 \pm 0.01$ & \\
\hline Root length $(\mathrm{cm}) \backslash$ & $4.1 \pm 0.02$ & $2.9 \pm 0.01$ & $2.7 \pm 0.01$ & $2.5 \pm 0.01$ & $2.2 \pm 0.01$ & $2.0 \pm 0.01$ & $1.8 \pm 0.01$ & $1.4 \pm 0.01$ & $1.2 \pm 0.01$ & $0.7 \pm 0.01$ & $0.6 \pm 0.01$ & $\mathrm{r}=-0.957(\mathrm{p} \leq 0.001)$ \\
\hline Root fresh weight(mg) & $7.2 \pm 0.06$ & $5.6 \pm 0.04$ & $5.1 \pm 0.04$ & $4.7 \pm 0.03$ & $4.3 \pm 0.03$ & $3.9 \pm 0.03$ & $3.5 \pm 0.02$ & $2.9 \pm 0.02$ & $2.6 \pm 0.02$ & $2.5 \pm 0.01$ & $2.2 \pm 0.01$ & \\
\hline Root dry weight(mg) & $2.7 \pm 0.05$ & $1.4 \pm 0.02$ & $1.3 \pm 0.02$ & $1.2 \pm 0.02$ & $0.9 \pm 0.01$ & $0.8 \pm 0.01$ & $0.6 \pm 0.01$ & $0.5 \pm 0.01$ & $0.3 \pm 0.01$ & $0.28 \pm 0.1$ & $0.25 \pm 0.0$ & \\
\hline \multirow[t]{3}{*}{ Chlorophyll content $\mathrm{mg} / \mathrm{g}$} & $3.04 \pm 0.06$ & $2.39 \pm 0.05$ & $2.27 \pm 0.05$ & $2.08 \pm 0.05$ & $1.87 \pm 0.04$ & $1.68 \pm 0.04$ & $1.47 \pm 0.03$ & $1.38 \pm 0.03$ & $1.24 \pm 0.03$ & $0.87 \pm 0.02$ & $0.68 \pm 0.02$ & $\mathrm{r}=-0.961(\mathrm{p} \leq 0.001)$ \\
\hline & $0.89+0.02$ & $0.66 \pm 0.02$ & $0.63 \pm 0.02$ & $0.61 \pm 0.02$ & $0.56 \pm 0.02$ & $0.52 \pm 0.02$ & $0.46 \pm 0.02$ & $0.4 \pm 0.02$ & $0.36 \pm 0.01$ & $0.31 \pm 0.01$ & $0.23 \pm 0.01$ & $\mathrm{r}=-0.952(\mathrm{p} \leq 0.001)$ \\
\hline & $3.93 \pm 0.09$ & $3.05 \pm 0.07$ & $2.90 \pm 0.07$ & $2.69 \pm 0.06$ & $2.43 \pm 0.06$ & $2.20 \pm 0.05$ & $1.93 \pm 0.04$ & $1.79 \pm 0.04$ & $1.60 \pm 0.04$ & $1.18 \pm 0.02$ & $0.91 \pm 0.02$ & $\mathrm{r}=-0.969(\mathrm{p} \leq 0.001)$ \\
\hline
\end{tabular}




\section{Effect of Topstar (Oxadiargyl 80\% W.P.)}

The different concentrations of Topstar (Oxadiargyl 80\% W.P.) considerably checked the chlorophyll contents of rice seedlings. The seedling of control set exhibited maximum chlorophyll - a contents $3.04 \pm 0.06 \mathrm{mg}$ at 14 days. However the chlorophyll - a contents of rice seedling exhibited $2.39 \pm 0.05 \mathrm{mg}$ with treatment of $0.5 \mathrm{ml} . /$ lit. concentration of Topstar (Oxadiargyl 80\% W.P.) at 14 days. The chlorophyll-a contents $0.68 \pm 0.02 \mathrm{mg}$ in 14 days old rice seedlings were found in treatment with $5 \mathrm{Mg}$./lit. concentration of Topstar (Oxadiargyl 80\% W.P.).

The seedling of control set exhibited maximum chlorophyll - $\mathrm{b}$ contents $0.89 \pm$ $0.02 \mathrm{mg}$ at 14 days. However the chlorophyll $-b$ contents of rice seedling exhibited $0.66 \pm$ $0.02 \mathrm{mg}$ with treatment of $0.5 \mathrm{ml} . / \mathrm{lit}$. concentration of Topstar (Oxadiargyl 80\% W.P.) at 14 days. Chlorophyll - b contents $0.23 \pm 0.01 \mathrm{mg}$ in 14 days old rice seedlings were found in treatment with $5 \mathrm{ml}$./lit. concentration of Topstar (Oxadiargyl 80\% W.P.).

The seedling of control set exhibited maximum total chlorophyll contents $3.93 \pm$ $0.09 \mathrm{mg}$ at 14 days. However the total chlorophyll contents of rice seedling exhibited $3.05 \pm 0.07 \mathrm{mg}$ with treatment of $0.5 \mathrm{Mg}$./lit. concentration of Topstar (Oxadiargyl 80\% W.P.) at 14 days. Total chlorophyll contents $0.91 \pm 0.02 \mathrm{mg}$ in 14 days old rice seedlings were found in treatment with $5 \mathrm{Ml} . /$ lit. concentration of Topstar (Oxadiargyl 80\% W.P.) (Table 6).

\section{Seed germination}

Generally all seed plants come across three important stages during their lifetime such (a) germination of embryo from seed (b) seedling stage and vegetative growth and (c) reproductive stage. During above three developmental stages various internal and external environmental factors affect the number of physiological biochemical and other vital functions that control the growth and development of concerned plants. During the process of germination activation and morphogenesis of dormant embryo take place, which are controlled by several internal and external conditions. According to Evenari (1961), germination is "sum of all the physiological processes occur inside the seed that start with the inhibition of water and ends with the protrusion of embryonic root in dicot and coleorhiza in monocots".

Saxena (1979) has reviewed on germination growth and yield of many crop seeds in relation to seed soaking (presoaking and presowing treatments). Muralikrisna and Saxena (1991) reported that time taken from seed soaking or presoaking to germination or seedling establishment vary with different crops and nature of internal and external conditions. Delayed emergence of redicle of coleorhizae may be due to deterioration of seedbed conditions such as water logging or scarcity, physico-chemical nature of soil i.e. temperature, $\mathrm{pH}$, and chemical composition of soil, attacked by mircorganisms, soil borne pests and other damages (Singh and Saxena, (1991). Bell (1993) and Vanhezewijk et al., (1993) reported that the process of germination hold better under appropriate and favourable environmental condition which include water, air, temperature, free from high salt concentrations an inhibitors and sometimes the spectral quality of light. The most important events of germination are enhanced by which the seeds imbibe till optimum level of water content is attained, hence any alternation or adulteration in water content affects the germination process. It is also reported that osmotic potential helps in making all the preparation in germination (Bhumbia et al., 1968; Saxena and Singh, 
1987 and Saxena, 1988) reported that high osmotie pressure caused due to high salt concentration the soil water cause the suppression of seed germination.

Reported are available on the correlation coefficient between germination and emergence of embryonic root or colcohiza (Chen et al., 1968; Heydeker, 1972 and Latito and Quagliotti, 1993) reported that following inhibition germination is an enzymatically activated process, mediated through on RNA. The control of enzyme production should be at the time of DNA transcription into m-RNA. The hormones perform a vital role in regulating the enzymatic activation during germination as determined by nucleic acid.

The role endogenous growth regulators during the seed germination can't be ruled out. The reserved starch present in endosperm is simplified by the action of various amylase enzymes. Hess (1975), suggested that $\alpha$ amylase in the endosperm is secreted by aleurone layer. Paleg (1960a and 1964) reported that application of $\mathrm{GA}_{3}$ stimulates the development of $\alpha$-amylase activity resulting in acceleration of seed germination in Barley. Paleg (1960a and 1964), Chrispeels and Jones (1980) reported that $\mathrm{GA}_{3}$ may act by affecting the substances causing mobilization of stored material localized in the storage tissue.

$\mathrm{GA}_{3}$ also increases the percent of polyribosomes resulting more protein synthesis that are utilized for morphogenesis (Frankland et al., 1971). Like GA 3 , IAA also influenced the germination process in various crop seeds. (Pandey and Sinha, 1988; Robertson et al., 1976, Acharya, 1994).The present experimental findings marked that Neem-oil, marshal (Carbosulfan 25\% E.C). Top star (oxadiargyl 80\% w.p.) considerably altered the process of germination in experimental rice cultivar.
Delay or inhibit the process of germination caused by different concentration of Topstar in test cultivar might have checked the amylase, proteolase and lipase activities or activation of hydrolytic enzymes in seeds such as luithirase, hyaleuronidase those are assist the breakdown of embryonic tissue.

Multi neem oil being a neem based pesticide, contains vast array of biological active chemicals such as protolimonoids, limonoids and non-isoprenoids, which act on crop pests by its larvicidial activities. They regulate different growth and development in insects and act effectively against many fungal diseases like smut, rust, powdery mild few and wilt (Singh, 1994). At molecular level both plant and animals are more or less similar and carryout same type of chemical and physiological activities during their growth and development and neem oil is hazardous to insects and pests, there is no guarantee that it might have not affecting on plant systems. Based on results obtained by the application of different concentrations of neem oil the possible mechanism of inhibitory affect on seed germination of test crop plant is discussed below.

Considerably checked of seed germination by all concentrations of neem oil/ranging from 0.5-5 ml/1 suggested limonoids might have checked or inhibited various physiological and biochemical processes associated with seed germination. Joshi and Prakash (1992) reported that leaf litter leachate of Melia azardichate exhibited inhibitory effects on germination of wheat, maize and pea. Similar reports suggested by Melkania (1984) on seed germination of turnip, barnyuard millet, finger millet, dock wheat and soyabean. Hence, the active ingredients present in neem-oil especially limonoids might have significantly inhibited the seed germination of three test crops. Since there are no much reports are available on the mode of actions on 
physiological and biochemical processes of neem-oil further in depth studies in this line are needed.

\section{Seedling growth and change in chlorophyll content}

Seedling establishment is considered as one of the crucial stage, after germination, where various morphogenesis activities are established along with changes in physiological and biological processes. During this period the seedlings try to become self-established by the development of root and shoot systems. The growth and development of shoot and root are controlled by various metabolic activities carried out in leaves, hence changes in shoot and root length of seedlings and their fresh and dry weights and changes in total chlorophyll contents are considered important parameters of seedling establishment.

All the concentration of neem-oil, marshal (carboslfan $25 \% \quad$ E.C) and Top star (Oxadiargyl 80\% W.P.) considerably reduced the seedling growth due to interaction of phytotoxins with photophosphorylation pathway and inhibition of light activated $\mathrm{mg}$ +2 ATPase activities (Moreland, 1980). Though the carbohydrate synthesis mainly depends on the efficacy of photosynthetic processes, the accumulation of carbohydrate in plants is directly proportional to the amount of chlorophyll present in the leaves.

The decrease in various parameters of seedling growth in the test crop is might be due to controlling of enzyme activities responsible for synthesis of plant growth regulators like $\mathrm{GA}_{3}$ and IAA that control shoot and root growth. Butler (1973) and Mishra and Adhikary (1986) reported that plant growth regulators, at lower concentrations induce synthesis of macromolecules resulting better seedling growth whereas higher concentration act as inhibitors.

Abdl Baki and Anderson (1972) suggested that many physiological and bio-chemical processes such as respiration fatty acid synthesis, protein synthesis, oxido-reduction reaction and several enzyme activities are associated with seedling vigor.

Vegetative growth of the plant body also depends on different environmental factors such as change in temperature, humidity, photoperiod and application of different agrochemicals (Bremner, 1969 (a \& b) and Cannel, 1969). It is quite common the most visible tillers die without producing grains and there may be many buds which never reach the visible stage (Davidson, 1964), Vergara et al., (1966) opinion that plant height is prime importance while working on the crop plants. Cleland (1964) suggested that gibberellins play important role on the growth of plants. Jones and Phillips (1966) suggested that in many plants highest level of gibberellins occur in apices of stem and root, young leaves, embryos and endosperm of developing seeds.

The application of different synthetic pesticides, herbicide and other biocides is a common and modern agricultural practice by the farmers for better yields, which more or less selectively interfere with growth of plant species. Further these chemical have a high toxicity on wide range of plants while others are very resistance to degradation in the environment and accumulate in the plants creating problems faster than they can solved. Moore (1965) suggested that all the biocides are not hazardous but most of them are toxic. A vast reports are available on effect of biocides several crop plants such as soya bean (Hsia and Cao, 1978), ragi (Kumar and Khan, 1982 and Acharya, 1994). Further due to advancement of biotechnologies, pesticides of 
plant origin (biological pesticide or biopesticides active) are developed and recorded for use. Neem oil is one of such biological derived pesticide having pesticidal active indegredients "Limonoids" which include azadiractuin, nimbocinal, epinimbocinal, nimbin, solamin and meliontriol. There are limonoid compound contain complex of active ingredients which act on crop pests by its larvicidal activities, disrupts, the growth process of insects, repellant or antifeedant to insect and act afectively against many fungal diseases like smut, rust, powdery mildew etc because of the above features neem oil is approved by the integrated pest management (IPM). As insects and pathogens die by the application of biocides, there is no guarantee that crop plants affected. These days may be significant in first generation but certainly these are physiologically are genetically hazardous as the plants and animals are more or less similar at molecular or sub-molecular level. Based on the results obtained by the application of different concentration of neem oil seedling growth of test cultivar the discussion are described below.

The seedling length, fresh and dry weight and chlorophyll content of the seedling of rice were significantly reduced by all concentrations of neem oil, carbosulfan and oxadiargyl which might be due to inhibiting and/or checking of protein, nucleic acids and carbohydrate synthesis. Such type of results have been reported by Kohli et al., (1988)on green gram, Padhy et al., (1992) on sesame, Jayakumar et al., (1990), Panda(1994) on ground nut by the eucalyptus globulus leaf leachate which contain allelochemics like phenolics, terpenoid and flavonoid which are more or less similar in structure and function of neem oil and other biocides. Further, it was reported that influence of biopesticide in relation to cell multiplication to auxin production in cells, influence of auxins on translocation of carbohydrates from source to sink are needed for better understanding on physiological and biochemical changes that occurs during seedling growth. Such type of related allelochemics present in neem oil might have suppressed various metabolic activities resulting decrease in seedling growth.

The decreased in height of plant suggests that the metabolites might have synthesized less and could not properly trans-located from source to sink. Murty et al., (1973) suggested that leaf thickness or specific leaf weight has significance correlation with photosynthetic rate per unit area in rice. Yoshida and Ahn (1968) observed that carbohydrate content of grain is largely depends on the amount of photosynthates formed after flowering.

The lower concentration of biocides caused higher rate of seed germination, but higher concentration exhibited negative correlation with germination process. The parameters of seedling growth (length, fresh an dry weight of both shoot and root and chlorophyll content of leaves, were significantly inhibited. Among different pesticides neem oil was found less toxic followed by carbosulfan and Oxadiargyl. Hence, effective training should be imparted to the paddy farmer on successful implementation of integrated pest management strategies for more productivity of crop and sustainable agriculture.

\section{References}

Abdul Baki and Anderson, J.D. 1941. Physiological and biochemical deterioration of seeds. In: seed Biology, 3: $283-315$.

Acharya, B., 1994. Studies on the effect of certain agrochemicals on seed germination, growth and yield of ragi (Eleusine coracana Gaertn.). Ph.D. Thesis, Berhampur University, Berhampur, Orissa, India. 
Anonymous, 1996a. Canada to ban two forms of carbofuran. Eur. Chem. News., 65: 27.

Anonymous, 1996b. Canada imposes carbofuran ban. Eur.Chem. News 65, 39.

Base!, vol. 2, Book of Abstracts. Convention Center, Base! p. 62.

Bell, D.T., 1993. The effect of light quality on the germination of 8 species from sandy habitats in western Australia. Aust. J. Bot., 41 (3): 321.

Bhumia*, D.R. Singh, B. and Singh, N.T., 1968. Effect of salt on seed germination.

Brahmachari, G., 2003. Neem an important plant.A retrospection, A European Journal of chemical Biology: 408- 421.

Bremner*, P.M.. 1969 b. Growth and yield of 3 varities of wheat with particular reference to the influence of unproductive tillers.

Butler, G.C., 1973. Principles of Ecotoxicology Scope - 12, John Wiley and sons, Chisester, New York, Brisbane: 350

Cannell, R.D., Gales, K, Snydon, R.M. and Suhail, B.A., 1979. Effect of short term water logging on the growth and yield of pea (Pisum sativum L). Ann. Appl. Biol; 93: $327-335$.

Chen, D, Sarid, S, and E. Kotchaliski, 1968. The role of water stress in the inactivation of messenger RNA of germinatory wheat embryos. Biochemistry. 61: 1378 - 1383

Chrispeels, M.J. and Jones, R.L.1980. The role of the endoplasmic reticulum in the mobilization of reserve macromolecules during seedling growth. Israel J. Bot. 29: 225-245.

Cleland: Role of endogenous auxin. Physiol. Plant. 17: 126 - 135

Crepeau, K.L., Kuivila, K.M., 2000. Rice pesticide concentrations in the Colusa Basin $\mathrm{Dr}<$ ! in and the Sacramento River, California, 1990- 1993. J. Environ. Qual. 29, 926-935.

Deuel Jr., L.E., Price, J.D., Turner, F.T., Brown, K.W., 1979.Persistence o f carbofuran and its metabolites, 3-keto and 3-hydroxy carbofuran, under flooded rice culture. $J$. Environ.Qual. 8, 23- 26.

Dickmann, R., Melgarejo, J., Loubiere, P. and Montagnon, M., 1997. Oxadiargyl: A new novel herbicide for rice and sugar cane Proceedings of the Brighton Crop Protection Council Conference - Weeds 1, 51-7. (Brighton Crop Protection.

Dietrich, D.R., Schmid, P., Zweifel, U., Schlatter, Ch., JenniEiermann, S., Bachmann, H., Bühler, U., Zbinden, N., 1995. Mortality of birds of prey following field application of granular carbofuran: a case study. Arch. Environ.Contam. Toxicol. 29, 140- 145.

Evenari, M., 1961. A survey of the work done in seed physiology by the Dept. of Botany, Bebrew. Univ. Jerusalem, Israel. Extension Bulletion No. 207: 1- 6.

Frankland*; B, Jarvis, B.C. and Cherry, J.H., 1971. RNA synthesis and the germination at light lettuce seeds.

Gupta, R.C., 1994. Carbofuran toxicity. J. Toxicol. Environ. Health 43, 383--418.

Hess, H., 1975. Regulation of germination and Evolution. In: Plant physiology, springer international editor. Narosa publishing house, New Delhi, PP. 259 - 261 Heydecker, W. (1972): Vigour In: Viability of seeds, Ed. Roberts, E.H. Chamman and Hall, London, PP. 209 253.

Heydecker, W., 1972. Vigour In: Viability of seeds, Ed. Roberts, E.H. Chamman and Hall, London, PP. 209 - 253.

Hsia, C.P. and Kao, C.H., 1978. Soyabean leaf disc senescence. Hormone action and hormon membrane permeability reaction. In: The Hindu Survey of Indian agriculture pp: 61 - 65: In plant physiology, Kalyani Public, New Delhi, 572 - 582. In: Proc. Int. Symp. on Current problems on Fruit and Vegetables. Los. Bonos. Loguna, 60: 273-277.

James, P.C., 1995. Internalizing externalities: granu lar carbofuran use on rapeseed in Canada. Eco!. Econ. 13, 181-1 84.

Jaya Kumar, M. Eyimi, M. and Pannierselvan, S., 1990. Alleolopathic effect of E. Globulus Labill on ground nut and corn. Comp. Physiol. Ecol. 15: 109 - 113.

Jones, R.L. and Phillips, D.R., 1966. Organs of gibberellin synthesis in light grown sun- 
flower plants.

Joshi, P.C. and Prakash, 1992. Allelopathic effect of litter extract of some tree species on germination and seedling growth of agricultural crops. In: Proc. First National Symposium Allelopathy in agroecq systems, Ed. P. Tauro, S.S. Narwal, 127 128.

Kohil, R.K., Kaur, K. and Kumari, A. 1988. Inhibition of seed germination of Vigna ambelata in response to Eucalyptus globules allelochemicals. In: proceedings of intl. cong. Plant physiol.. Society of plant physiol. And biochem., New Delhi: 15-50.

Kumar*, K.B. and Khan, P.A., 1982. Effect of insecticides oxydemeton methyl and Dimenthoate on chlorophyll retention and hydrogen peroxide utilization in Ragi (Exeusive coracana Gacrth CV PR 202) leaves during senescence.

Leake, C. R., 1998. Proc. 9th IUPAC Int. Congr. Pestic. Chem., London, 2, 5A-021.

Lotito, S. and Quagliotti, L., 1993. The influence of storage temperature and moisture content on seed viability in pepper (Caopsicum annum). Agronomic, 13 (3): $231-235$.

Mabury, S.A., Crosby, D.G., 1996. Pesticides reactivity toward hydroxyl and its relationship to field persistence. J. Agric. Food Chem. 44, 1920-1924.

Malik, C.P., 1981. The physiology of seed development and germination. In: Plant Physiology, Pp. 572-582. Kalyani Publishers, New Delhi.

Marsden*, P.J., Kuwano, E., Fukuto, T.R., 1982. Metabolism of carbosulf an [2, 3-d ihydro-2, 2-dimethy1benzofuran-7-yl(dinbutylaminothio).

Melkania, N.P. 1984. Influence of leaf leachate of certain woody species in agricultural crops. Indian j. Ecol., 11: 82 - 86

Mishra A and Adhikary S.P., 1988. Effect of different neem preparations on growth protein content, Nitrogen fixation and extracellular amino-acids of Anabaena variables. UU 147.

Moore, K.G., 1965. Senescence of leaves of
Acer pseudoplantanus $\mathrm{L}$ and Parthenocissus aricuspidalis plarch 1, changes in some leaf constituents during maturity and senescence.

Moreland, D.E., 1980. Mechanism of action of herbicides. Ann. Rev. Plant. Physiol; 31: 597.

Murallikrishna, S. and Saxena, O.P., 1991. Germination behavior of wheat seeds as influenced by different moisture regims, soaking duration and temperature. In: Proc. Intl. Seed Symp. (Eds. N. David Sen and S. Mohammed), Jodhapur, India, Pp. 299-302.

Murty, K.S. Nayhak, S.K. and Sahu, G., 1973. Photosynthetic efficiency in rice varieties. ISNA. News Letter, 2; $5-6$

Norberg-King, T.J., Durhan, E.J., Ankley, G.T., 1991. Application of toxieity identification evaluation procedures to the ambient waters of the Colusa Basin Drain, California. Environ. Toxicol. Chem. 10, 891-900.

Padhy B, Khan P.A., Acharya B and Buxi Patro N.P., 1992. Allelopathic effects of Eucalyptus leaves on seed germination and seedling growth of finger millet. In: Proc. of First National Symposiums on Allelopathy in Agroecosystems, (Eds. P. Tauro and S.S. Norwal), Indian Society of Allelopathy. Haryana Agriculture University, Hisar, India, Pp. 102-104.

Paleg*, L.G., 1960. Physiological effects of gibberlic acid. I. on carbohydrate metabolism of barley endosperm.

Panda, P., 1994. Allelopathic studies on crop plants, M.Phil. Dissertation, Berhampur University, Berhampur, Odisha, India.

Pandey, S.N. and Sinha, B.K., 1998. Plant growth regulators In: Plant physiol Vikas publish. House Pvt. Ltd., P.P. 424 - 465.

Peleg, L.G., 1964. cellular localization of the gibberellin induced response of barley endosperm $5^{\text {th }}$ Int. Natn. Conf. Plant growth Reguln. Paris.

Ramanand, K., Sharmila, M., Singh, N., Sethunathan, N., 1991. Metabolism o f carbamate insecticides by resting cells and cell-free preparations of a soil 
bacterium, Arthrobacter sp. Buli. Environ. Contam. Toxicol. 46, 380- 386.

Robertson, J. Hill man and Berrie AMM.1976. The involvement of indoleacetic acid in the thermo-dormancy of lettuce fruits, Lactuca sativa or Grand Rapids. Planta, 131: $309-313$.

Sahoo, A., Sahu, S.K., Sharmila, M., Sethunathan, N., 1990. Persistenee of carbamate inseetieides, earbosulfan and carbofuran in soils as influenced by temperature and microbial activity. Buli. Environ. Contam. Toxicol. 44, 948-954.

Saxena*, O.P., (1988). Bichemical studies on instant germination in carrot (Dauscus carrota L.).

Saxena, O.P. and Singh, G., 1987. Osmotic principle, studies in some vegetable seeds. Acta. Hort., 215: 201-207.

Schmutterer, H., 1990. Properties and potential of natural pesticides from the neem tree, Azadirachta indica. Annu. Rev. Entomol. 35:271--297.

Seiber, J.N., Catahan, M.P., Barrill, C.R., 1978. Loss of carbofuran from rice paddy water: ehemieal and $\mathrm{p}$ hysieal faetors. $J$. Environ. Sei. Health 13(B), 131- 148.

Sexena, O.P., 1979. Physiological aspects of seed germination in: Current advances in plant reproductive biology. (Ed. Malik, C.P.): $323-348$.

Singh, G. and Saxena, O. P., 1991. Physiological and biochemical studies associated with instant germination in tomato. In: Proc. Intl. Seed Symp., (Eds., David N. Sen and S. Mohammed), PP. 313-317.Jodhpur, India.
Singh, R.S., 1994. Impact of neem and its products in plant disease management. In: Abstracts international symposium on Allelopathy in sustainable agriculture, forestry and environment. Eds. S.S. Narwal and P. Tauro, P.P. 116.

Tejada, A.W., Magallona, E.D., 1985. Fate earbosulfan in a rice paddy environmental. Philipp. Entomol. 6: 255273.

Trevizan, L.R.P., Mattos, M.L., Martins, J.F.S., Baptista, G.C., Mello, M., Dias, R.A., 2002. Carbofuran and 3-hydroxyearbofuran residues in irrigation water of a rice ecosystem in Southern Brazil. In: 1Oth International Congress on the Chemistry of Crop Protection, 10, 2002,

Umetsu, N., Fukuto, T.R., 1982. Alternation of carbosulfan [2, 3-dihydro-2, 2-dimethyl7-benzofuranyl

(Di-nbutylaminosulfenyl) methylcarbamate] in lhe rat stomach. J. Agric. Food Chem. 30, 555- 557.

Vanhezewijk, M.J.; Vanbeem, A.P.; Verkleij, J.A.C. and Pleterra, A.H., 1993. Germination of Orobance erenata seeds as influenced by conditioning temperature and period. Can. J. Bot., 71(b): 786-826.

Vergara, B. S., 1966. Crop response to light variations. Relationship between growth duration and grain yield of rice plants. Soil Sci. and Plant. Nutr., 12: 137-153.

Yoshida*, S. and Ahn, S.B., 1968. The accumulation process of carbohydrate in rice verities in relation to their response to nitrogen in the tropics.

\section{How to cite this article:}

Rath, B.B. and Adhikary, S.P. 2018. Assessment the Influence and Efficacy of Some Biocides on Rice Plants. Int.J.Curr.Microbiol.App.Sci. 7(10): 1326-1347. doi: https://doi.org/10.20546/ijcmas.2018.710.149 